\title{
The Effect of Estrogen on the Transcription of the Insulin-like Growth Factor-I Gene in the Uterus
}

Inseok Kwak*

Department of Biological Sciences, Silla University, Busan 617-736, Korea

Received May 8, 2009 /Accepted May 21, 2009

The uterus plays a critical role in pregnancy and steroid hormones, and both estrogen (E2) and progesterone (P4) especially play important roles in the cross-talk between embryos and uterus to support the pregnancy. E2 stimulates uterine growth during early pregnancy to prepare for implantation of embryos. This cross-talk during the implantation period involves hormones (E2 and P4) and growth factors, including insulin-like growth factor-I (IGF-I). In the uterus of a pregnant pig, the action of E2 is mediated by estrogen receptor- $\alpha(\mathrm{ER}-\alpha)$. The expression of ER-a was much higher in early pregnancy than in mid- and late- pregnancy, suggesting E2 secretion from embryos enhances transcription of ER-a during early pregnancy. In order to prove whether IGF-I is an E2 target gene, quantitative real-time PCR was performed on ovariectomized murine uterus with E2 and/or P4 treatment(s). Increased IGF-I mRNA expression was observed with E2 treatment, however, it was not significantly induced by $\mathrm{P} 4$ treatment, which clearly demonstrates that, in mice, E2 depends on the activation of uterine IGF-I gene expression. The expression of IGF-I in the uterus of pigs was much higher in early pregnancy than in mid- and late- pregnancy and these data exhibited the same expression pattern with the ER- $\alpha$ gene expression in the uterus. It suggests that a positive $\mathrm{co}^{-}$-relationship between IGF-I and ER- $\alpha$ expression exists in the uterus, and that both gene expressions of IGF-I and ER- $\alpha$ are regulated by E2. It further suggests that uterine the IGF-I gene expression might be initiated by E2 secreted from embryos to increase ER- $\alpha$ gene expression, and that this increased ER- $\alpha$ further stimulates the expression of IGF-I in the uterus during early pregnancy.

Key words : Estrogen, estrogen receptor- $\alpha$, insulin-like growth factor-I, progesterone, uterus

\section{Introduction}

In mammals, the survival of a species depends upon the establishment and maintenance of pregnancy. Successful pregnancy requires the orchestration of complex and precise interactions between the embryo(s) and maternal uterus and ovary. The embryonic-maternal cross-talk during pregnancy involves hormonal and biochemical factors as well as cell/tissue interactions between the uterus and embryos. Combined actions of steroid hormones, especially estrogen (E2) and progesterone (P4) are critical factors for the uterus receptive and successful pregnancy. E2 secretion from embryos, which is known as a signal for maternal recognition of pregnancy occurs at peri-implantation in pigs [1] and the pre-surge of E2 stimulates uterine epithelial cell proliferation during early pregnancy in mice [15].

E2 secretion from embryos is coincident with the temporally high expression of insulin-like growth factor-I (IGF-I) in the porcine uterus $[5,17]$. Local and temporally regulated

*Corresponding author

Tel : +82-51-999-6307, Fax : +82-51-999-5176

E-mail:ikwak@silla.ac.kr expressions of IGF-I in the uterus and embryo secretion of E2 at peri-implantation suggest an autocrine/paracrine role(s) for IGF-I and E2 in the orchestration of maternal and embryonic interactions for growth and differentiation [3,7, 12]. Although IGF-I is known to be a mediator of estrogen-induced uterine growth, there is only limited information available regarding the molecular mechanism(s) responsible for the transcriptional regulations of IGF-I by E2 in the uterus during pregnancy. The objectives of this study is to elucidate the molecular mechanisms involved in transcriptional regulation of IGF-I and $\mathrm{ER}-\alpha$ by $\mathrm{E} 2$ in the uterus using two animal systems. Due to technical difficulties of ovariectomy in pig, mouse was used ovariectomy for the removal of endogenous E2 and P4 and then E2 and P4 were treated to see the effects of both steroid hormones on the expression of the IGF-I gene in the uterus.

\section{Materials and Methods}

Animals and tissue preparation and primary cell
cultures

For technical reason, ovariectomy was only performed in 
mice, not in pigs. Groups of wild-type mice were ovariectomized, and 2 weeks later, these mice were injected with control, E2 (0.1 $\mu \mathrm{g} / \mathrm{mouse}), \mathrm{P} 4$ ( $1 \mathrm{mg} / \mathrm{mouse})$, or E2 plus P4 for $4 \mathrm{hr}, 24 \mathrm{hr}$ or $48 \mathrm{hr}$ (Sigma-Aldrich, St. Louis, MO). The injections were repeated every $12 \mathrm{hr}$ for the $24 \mathrm{hr}$ and $48 \mathrm{hr}$ and then sacrificed to collect uterus. Pigs were bred at estrus (day 0 ) and were slaughtered on the indicated days of pregnancy and uterus and other tissues were removed. Uterus was collected from day (d) 12 pregnant pigs, and its three major cell types were isolated by differential centrifugation after enzymatic digestion including trypsin and collagenase. In brief, a sterilized $38 \mathrm{uM}$ stainless steel sieve (Thomas Scientific, Newark, NJ) was used for the separation of the cells. Stromal (St) cells passed through the sieve with the filtrate, while glandular epithelial (GE) cells were retained. Luminal epithelial (LE) cells were pelleted from low speed centrifugation $(800 \times g, 7 \mathrm{~min})$ [16]. GE, LE and St cells were maintained for the primary cell cultures and cells were used after reaching $80 \%$ of confluence.

RNA isolation, RT-PCR and quantitative real-time PCR

Total RNA was isolated from uterus of pigs at specific days of pregnancy and mice at specific times after steroid treatment using Trizol reagent from Life Technologies (Gaithersburg, MD). Expression levels of mRNA for IGF-I were measured by RT-PCR using porcine samples. For the quantitative real-time RT-PCR for the mouse uterus, TaqMan analysis were performed using the ABI Prism 7700 Sequence Detector System (PE Applied Biosystems, Foster City, CA). For IGF-I and 18S rRNA, pre-validated probes and primers were purchased from Applied Biosystems. RT-PCRs were performed using One-step RT-PCR Universal Master Mix reagent and TaqMan Gene Expression Assays (Applied Biosystems, Foster City, CA). All real-time PCRs were done by using the three independent RNA sets and mRNA quantities were normalized against 18S rRNA using ABI rRNA control reagents. Polymerase chain reaction (PCR) (30 sec at 950C, $30 \mathrm{sec}$ at 550C, and $1 \mathrm{~min}$ at 720C, and 30 cycles) was performed with $0.2 \mu$ of first cDNA strand previously synthesized from total RNA. The sequences of each primer used for RT-PCR of IGF-I mRNA were as follows: forward primer (F): 5' - ATGCACATCACATCCTCTTGG- 3', which is exon III-specific and reverse primer (R): $5^{\prime}-$ CATCT CCAGCCTCCTCAGATC $-3^{\prime}$, which is exon IV-specific. The sequences of each primers used for RT-PCR were as follows: specific for ER- $\alpha$ : (F): 5'- ATTGGTCTTGTCTGGCGCTCC - $3^{\prime}$ and (R): $5^{\prime}-$ GGTCATAGAGGGGCACCACGT $-3^{\prime}$, and specific for glyceraldehyde $3^{-}$phosphate dehydrogenase (GAPDH) for an internal RT-PCR control : (F): 5'- AAGTGG ACATTGTCGCCAT $-3^{\prime}$ and (R): 5' - TCACAAACATGGGGG CATC $-3^{\prime}$.

\section{Results and Discussion}

\section{The expression of $E R-\alpha$ in the uterus during pregnancy}

The ovarian steroid hormone estrogen (E2) is a critical regulator of the female reproduction and most of the physiological roles of $\mathrm{E} 2$ are mediated by cognate nuclear receptors, one of two estrogen receptor (ER) forms, ER- $\alpha$ or ER- $\beta$, which are encoded by two separate genes $[8,19]$. ER is known as the nuclear receptor, which acts as transcription factor $[2,18]$.

In order to examine gene expression of ER-a in the porcine uterus during pregnancy, RT-PCR analysis was performed. The orders of expressions of the pig ER-a gene transcripts were day (d) 12 cycling $>>d 12$ pregnant $(\mathrm{Px})$ $>$ d 60 Px $>$ d 90 Px uterus (Fig. 1), where d 12 is a peri-implantation period and d 60 and d 90 are mid- and late- pregnancy, respectively. These results indicate that pre-surge of E2 in cycling uterus and E2 secretion from embryos during early pregnancy enhanced transcription of ER-a in the uterus. In contrast, the expression of ER-a at mid- or latepregnancy was not observed or minimal. These results imply that P4 from corpora lutea (CL) in pregnant animal diminished ER-a expression in the mid- or late- pregnant uterus. It also explains why the expression of ER-a in d 12 cycling uterus is much higher than the expression in $\mathrm{d} 12$ pregnant uterus. As pregnancy progresses, the concentration of P4, secreted from the newly formed $\mathrm{CL}$, in pregnant uterus is

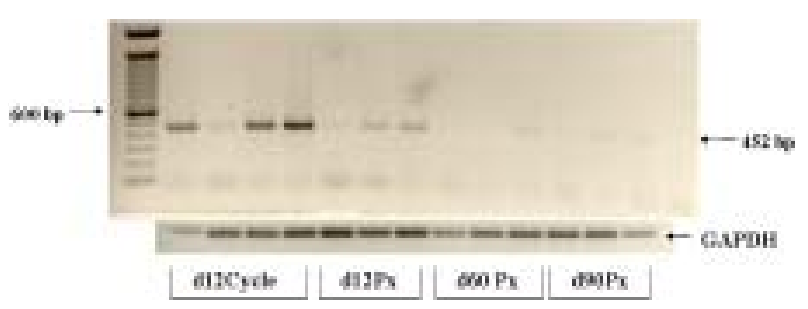

Fig. 1. The expression pattern of $\mathrm{ER}-\alpha$ in the uterus during the early- (d 12), mid- (d 60) and late- (d 90) pregnancy and in the cycling ( $\mathrm{d} 12)$ in pig. (Px and Cycle represent pregnant and cycling, respectively). 
higher than the cycling uterus and higher level of P4 diminished ER-a expression in early pregnancy compared with cycling uterus. In contrast, the expression of ER- $\beta$ in the uterus was not observed at any stages of pregnancy (Data not shown). Gene ablation studies have demonstrated that the $\mathrm{ER}-\alpha$ is a primary regulator of uterine function for the E2. Out of two estrogen receptors, ER $-\alpha$ and ER $-\beta$, only ER- $\alpha$ is a functional in the uterus $[8,19]$, while $\mathrm{ER}-\beta$ is a functional in the ovary [9].

Transcriptional regulation of IGF-I by E2 in the uterus

In mice, pre-ovulatory $\mathrm{E} 2$ surge stimulates uterine proliferation during early pregnancy [15]. In pigs, E2 secretion from embryos occurs at peri-implantation period $[1,12]$. The treatment of E2 stimulates DNA synthesis, especially in epithelial cells of the uterus in early pregnancy $[10,14]$. One of the genes identified as a target for regulation by the E2 in the uterus is insulin-like growth factor-I (IGF-I) [6,17]. IGF-I is a key regulator of cellular growth- and differentiation, and is synthesized in a variety of tissues [11]. Although the liver is considered to be the main source of circulating IGF-I, the local actions of IGF-I have been studied in many tissue including uterus [6,17]. Embryonic secretion of E2 and temporal high expression of IGF-I in the uterus occurs at peri-implantation period in the pig [17]. The increased IGF-I mRNA in the uterus further induces $\mathrm{ex}^{-}$ pression of embryonic aromatase, which is an enzyme responsible for the synthesis of $\mathrm{E} 2[6,12]$.

In order to examine the role of $\mathrm{E} 2$ in uterine IGF-I gene expression in the mouse, quantitative real-time PCRs were

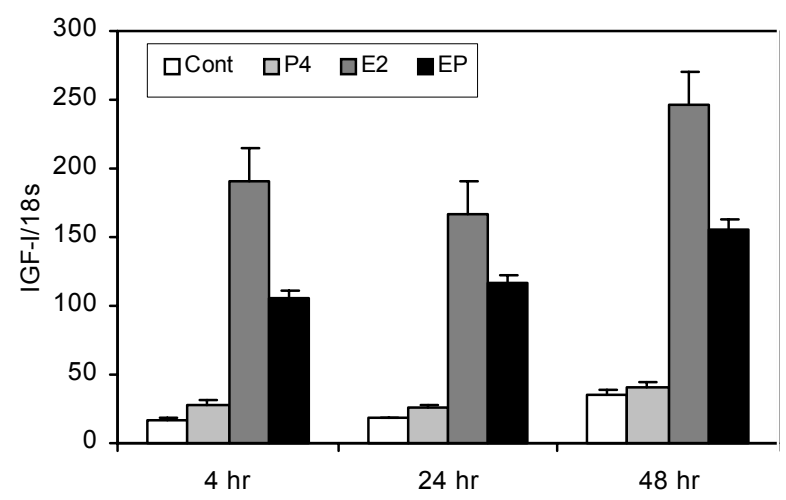

Fig. 2. Regulation of the IGF-I expression by estrogen (E2), progesterone (P4) or E2+P4 (EP) in mouse uterus by quantitative real-time RT-PCR analysis. The results represent the mean \pm SE of three independent RNA sets and IGF-I mRNA quantities were normalized by $18 \mathrm{~S}$ rRNA. performed using ovariectomized mice to remove endogenous E2 and P4. The maximally increased IGF-I mRNA transcripts in the mouse uterus was observed after 4 hours E2 treatment and the increased IGF-I mRNA transcripts were still observed after 48 hours continuous E2 treatment (Fig. 2). However, slightly increased IGF-I gene expression by P4 treatment at 4 hours was observed. Furthermore, the combined treatment of E2 plus P4 markedly inhibited transcription of IGF-I compared with E2 treatment only. These results clearly demonstrate estrogen dependent activation of IGF-I gene expression in the uterus.

In order to examine IGF-I mRNA abundance in the uterus of pigs during pregnancy, RT-PCR was performed using uterus RNA samples. The expression of IGF-I mRNAs was greater in the uterus of pigs at peri-implantation than later stages of pregnancy, and the expression of IGF-I transcript was higher at d 60 (mid pregnancy) than d 90 (late pregnancy). (Fig. 3). These data mimicked the expression pattern of the ER- $\alpha$ gene (Fig. 1) and expressions of the ER- $\alpha$ and IGF-I were higher in early pregnancy than mid pregnancy and expression of late pregnancy was the lowest (d 12 Px $>\mathrm{d} 60 \mathrm{Px}>\mathrm{d} 90 \mathrm{Px}$ ). It suggests that there is a very strong positive co-relationship between IGF-I and ER- $\alpha$ expressions in the uterus during pregnancy. It suggests that both IGF-I and ER- $\alpha$ gene expressions are E2 dependent. Both mice with null mutations of the IGF-I [13] or ER- $\alpha$ [4] are infertile and these mice possess an infantile uterus that suggests the involvement of IGF-I and $\mathrm{ER}-\alpha$ in the local growth and differentiation of the uterus.

It is known that E2 surge stimulates uterine epithelial cell proliferation during early pregnancy and as pregnancy progresses, P4 secreted from corpora lutea, initiates uterine stromal cell proliferation $[10,15]$. In order to examine the IGF-I gene expressions from different cell types of early pregnant uterus, three major cell types were isolated and primary cultures of glandular epithelial (GE), luminal epithelial (LE), and stromal (St) cells were used for RT-PCR analysis. Interestingly,

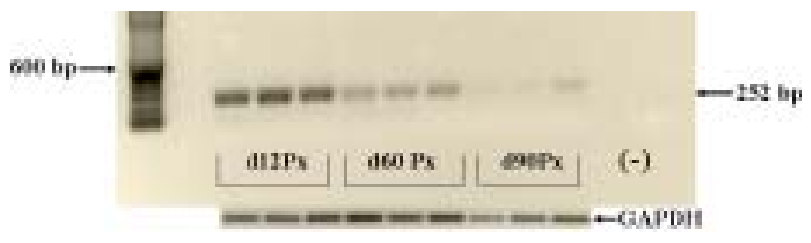

Fig. 3. The expression pattern of IGF-I in the uterus during pregnancy. RT-PCR was done by using the three independent RNA sets of the early- (d 12), mid- (d 60) and late- (d 90) pregnancy (Px). 


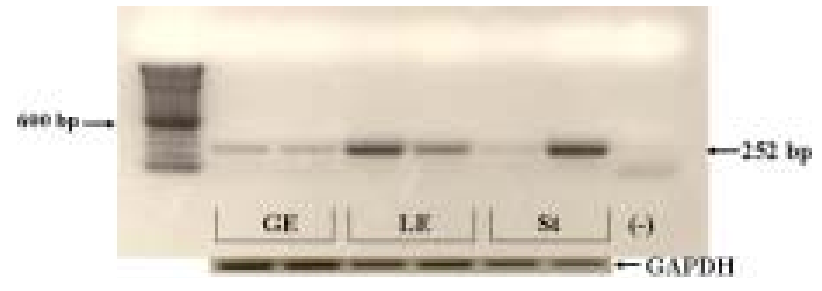

Fig. 4. The expression pattern of IGF-I in different cell types from early pregnant (d 12) uterus. Three major cell types of the uterus were isolated and primary cultures of glandular epithelial (GE), luminal epithelial (LE), and stromal (St) cells were used for RT-PCR analysis. RT-PCR was done by using two independent RNA sets of samples.

the expression of IGF-I message was greater in LE cells than in St cells and the lowest in GE cells, demonstrating cell type-specific expression of this gene (Fig. 4). It suggests that IGF-I is required for E2 induced luminal epithelial cell proliferation, which is most outside layer of the uterus.

Hence, these studies were performed to elucidate molecular mechanism of $\mathrm{E} 2$ in the regulation of uterine IGF-I gene expression, The IGF-I gene expression in the uterus can be initiated by estrogen acting through its own receptor (ER-a) and increase ER-a gene expression and this increased ER-a can function as a transcriptional factor to stimulate the local gene expression of IGF-I in the uterus.

\section{References}

1. Bazer, F. W. and W. W. Thatcher. 1977. Theory of maternal recognition of pregnancy in swine based on estrogen controlled endocrine versus exocrine secretion of prostaglandin F2alpha by the uterine endometrium. Prostaglandins 14, 397-400.

2. Chaudhuri, G. 2008. Nuclear receptors and female reproduction: a tale of 3 scientists, Jensen, Gustafsson, and O'Malley. Reprod. Sci. 15, 110-120.

3. Choi, I., R. C. Simmen, and F. A. Simmen. 1996. Molecular cloning of cytochrome P450 aromatase complementary deoxyribonucleic acid from periimplantation porcine and equine blastocysts identifies multiple novel $5^{\prime}$-untranslated exons expressed in embryos, endometrium, and placenta. Endocrinology 137, 1457-67.

4. Couse, J. F. and K. S. Korach. 1999. Estrogen receptor null mice: what have we learned and where will they lead us? Endocr. Rev. 20, 358-417.

5. Hofig, A., F. J. Michel, F. A. Simmen, and R. C. Simmen. 1991. Constitutive expression of uterine receptors for insulin-like growth factor-I during the peri-implantation period in the pig. Biol. Reprod. 45, 533-539.

6. Klotz, D. M., S. C. Hewitt, P. Ciana, M. Raviscioni, J. K. Lindzey, J. Foley, A. Maggi, R. P. DiAugustine, and K. S.
Korach. 2002. Requirement of estrogen receptor-alpha in insulin-like growth factor-1 (IGF-1)-induced uterine responses and in vivo evidence for IGF-1/estrogen receptor cross-talk. J. Biol. Chem. 277, 8531-8537.

7. Ko, Y., I. Choi, M. L. Green, F. A. Simmen, and R. C. Simmen. 1994. Transient expression of the cytochrome P450 aromatase gene in elongating porcine blastocysts is correlated with uterine insulin-like growth factor levels during peri-implantation development. Mol. Reprod. Dev. 37, 1-11.

8. Korach, K. S., J. M. Emmen, V. R. Walker, S. C. Hewitt, M. Yates, J. M. Hall, D. L. Swope, J. C. Harrell, and J. F. Couse. 2003. Update on animal models developed for analyses of estrogen receptor biological activity. J. Steroid Biochem. Mol. Biol. 86, 387-391.

9. Krege, J. H., J. B. Hodgin, J. F. Couse, E. Enmark, M. Warner, J. F. Mahler, M. Sar, K. S. Korach, J. A. Gustafsson, and O. Smithies. 1998. Generation and reproductive phenotypes of mice lacking estrogen receptor beta. Proc. Natl. Acad. Sci. U S A 95, 15677-15682.

10. Lee, K., J. Jeong, M. - J. Tsai, S. Tsai, J. P. Lydon, and F. J. DeMayo. 2006. Molecular mechanisms involved in progesterone receptor regulation of uterine function. J. Steroid Biochem. Mol. Biol. 102, 41-50.

11. LeRoith, D. and C. T. Roberts, Jr. 1993. Insulin-like growth factors. Ann. N. Y. Acad. Sci. 692, 1-9.

12. Letcher, R., R. C. Simmen, F. W. Bazer, and F. A. Simmen. 1989. Insulin-like growth factor-I expression during early conceptus development in the pig. Biol. Reprod. 41, $1143-1151$.

13. Liu, J. P., J. Baker, A. S. Perkins, E. J. Robertson, and A. Efstratiadis. 1993. Mice carrying null mutations of the genes encoding insulin-like growth factor I (Igf-1) and type 1 IGF receptor (Igf1r). Cell 75, 59-72.

14. McEwan, I. J. 2009. Nuclear receptors: one big family. Methods Mol. Bio. 505, 3-18.

15. Paria, B. C., Y. M. Huet-Hudson, and S. K. Dey. 1993. Blastocyst's state of activity determines the "window" of implantation in the receptive mouse uterus. Proc. Natl. Acad. Sci. U S A 90, 10159-10162.

16. Reed, K., L. Badinga, D. L. Davis, T. E. Chung, and R. C. Simmen. 1996. Porcine endometrial glandular epithelial cells in vitro: transcriptional activities of the pregnancy-associated genes encoding antileukoproteinase and uteroferrin. Biol. Reprod. 55, 469-477.

17. Simmen, F. A., R. C. Simmen, R. D. Geisert, F. Martinat-Botte, F. W. Bazer, and M. Terqui. 1992. Differential expression, during the estrous cycle and pre- ${ }^{-}$and post-implantation conceptus development, of messenger ribonucleic acids encoding components of the pig uterine insulin-like growth factor system. Endocrinology 130, 1547-1556.

18. Tsai, M. - J. and B. W. O'Malley. 1994. Molecular mechanisms of action of steroid/thyroid receptor superfamily members. Annual Review of Biochemistry 63, 451-486.

19. Weihua, Z., S. Andersson, G. Cheng, E. R. Simpson, M. Warner, and J. A. Gustafsson. 2003. Update on estrogen signaling. FEBS Lett. 546, 17-24. 
초록 : 자궁 내 insulin-like growth factor-I 유전자 발현에 미치는 에스트로겐의 영향

곽 인 석*

(신라대학교 의생명과학대학 생물과학과)

자궁은 임신에 필수불가결한 기관으로, 에스트로겐(E2)과 프로게스테론(P4)은 태아와 자궁 사이의 상호 신호전 달을 적절하게 조절하여, 임신을 확립하게 하는 필수적 요소이다. 임신 초기 $\mathrm{E} 2$ 는 배아의 안정적인 착상을 위하여 자궁의 성장을 촉진하는 역할을 담당한다. 이 시기 자궁에서 분비되는 인슐린유사 성장인자-I(IGF-I)와 E2/P4 간의 상호 신호전달이 임신 확립에 있어서 매우 중요한 역할을 한다. $\mathrm{E} 2$ 는 에스트로겐 수용체 $(\mathrm{ER})$ 에 의해 그 작용이 결정되어지는데, 임신 돼지 자궁에서는 $\mathrm{ER}-\alpha$ 만이 발현됨을 증명하였다. 자궁에서 $\mathrm{ER}-\alpha$ 의 발현은 임신 중기나 말기 보다 임신 초기 단계에서 높게 발현됨이 관찰되었다. 이는 배아에서 분비되는 E2가 ER- $\alpha$ 의 발현을 증가시키는 역할을 함을 보여주는 결과이다. IGF-I이 E2 표적 유전자임을 증명하기 위하여 난소를 제거한 쥐에 $\mathrm{E} 2 / \mathrm{P} 4$ 를 처리한 후 IGF-I의 발현을 측정한 결과, E2를 처리한 샘플에서는 IGF-I의 발현이 크게 증가하였으나, P4를 처리한 샘플에서 는 큰 영향을 받지 않는 것으로 나타났다. 이 결과는 E2가 자궁에서 IGF-I의 발현을 증가시키는 역할을 수행함을 직접적으로 증명하였다. 임신한 돼지의 자궁에서 임신 시기별로 IGF-I 유전자의 발현을 조사한 결과 임신 초기에 가장 높은 발현을 보였고, 이 양상은 ER- $\alpha$ 의 발현 형태와 아주 유사한 패턴을 나타내었다. 이는 임신 자궁에서 $\mathrm{ER}-\alpha$ 와 IGF-I의 발현이 상호 연관되어 있으며 ER- $\alpha$ 와 IGF-I은 E2에 의해서 조절되어지는 유전자이며, 임신초기 배아에서 분비되는 E2가 자궁에서 ER- $\alpha$ 의 발현을 증진시키고, 나아가서 이 ER- $\alpha$ 가 자궁에서 IGF-I 유전자의 발현을 증가시키는 역할을 함을 보여주는 결과이다. 